\title{
Distribution of DNA, nuclear micro-heterogeneities and compaction of the chromatin in rabbit epididymal spermatozoa. Ultrastructural evaluation of the Feulgen-like technique using osmium ammine
}

\author{
JL Courtens ${ }^{1}$, M Biggiogera ${ }^{2}$, S Fakan ${ }^{2}$ \\ 1 INRA, Laboratoire de Physiologie de la Reproduction des Mammifères Domestiques, \\ 37380 Nouzilly, France; \\ 2 Centre de Microscopie Électronique de l'Université de Lausanne, \\ 27, rue du Bugnon, 1005 Lausanne, Switzerland
}

(Received 31 January 1994; accepted 23 March 1994)

\begin{abstract}
Summary - An adaptation of the Feulgen procedure to visualise DNA at the ultrastructural level, using osmium ammine instead of Schiff reagent, was applied to ultrathin sections of rabbit epididymal spermatozoa, known to display increasing chromatin compaction as they progress through the epididymis. In contrast with the somatic cell nuclei of the epididymal epithelium, which display classical staining, the chromatin of spermatozoa is partly or fully destroyed during the hydrolysis step of the technique. The sperm chromatin resistance towards destruction is a function of the initial sperm nuclear compaction and of the duration of hydrolysis prior to Feulgen-like staining. For a given nucleus, the maximum staining intensity is only obtained after an optimal duration of hydrolysis. However, because of this duration and local differences in chromatin compaction, the total DNA of a section is never completely visualised. The most compact parts of the nuclei are not yet stained, when the less compact parts have already been destroyed. This gives rise to a sperm-specific pattern which corresponds to the enhancement of microheterogeneities present in all sperm nuclei and to the local depolymerisation of the nuclear material during hydrolysis. The depolymerised parts of nuclei sit over the sections, and they also bind uranyl acetate, ethidium bromide and anti-protamine antibodies. Therefore, in sperm nuclei, the Feulgenlike staining at the ultrastructural level does not reveal the true DNA distribution. However, the amount of staining can be quantified to evaluate sperm chromatin compaction.
\end{abstract}

rabbit epididymal spermatozoa / DNA electron microscopic cytochemistry / ethidium bromide / protamine immunocytochemistry/sperm compaction

Résumé - Distribution de l'ADN et compaction de la chromatine des spermatozoïdes épididymaires de lapin. Évaluation d'une variante de la technique de Feulgen en microscopie électronique ( $\mathrm{HCl}-\mathrm{Osmium}$ ammine). Le remplacement du réactif de Shiff par une ammine d'osmium permet de colorer l'ADN, après son hydrolyse acide, par une réaction de type Feulgen visible en microscopie électronique (Cogliati et Gautier, 1973). Elle est ici utilisée sur des spermatozoïdes épididymaires de lapin, dont la chromatine est en cours de compaction, et sur les 
cellules somatiques de l'épithélium épididymaire. Bien que ces dernières se colorent classiquement, les noyaux de spermatozoïdes, présents dans les mêmes coupes, sont partiellement détruits par l'hydrolyse. Leur résistance globale à la destruction dépend de leur condensation moyenne initiale et de la durée de l'hydrolyse qui précède la coloration. Quantitativement, la meilleure coloration des noyaux est obtenue après un temps d'hydrolyse optimal, d'autant plus court que les noyaux sont moins compacts. Seule la détermination de ce temps permet d'évaluer la compaction de la chromatine. Toutefois, que l'hydrolyse soit optimale ou non, la totalité de l'ADN d'un noyau n'est jamais colorée. Les parties les plus compactes ne sont pas encore réactives quand d'autres sont déjà détruites. Les taches d'ADN colorées correspondent à des sites où la chromatine dépolymérisée forme des protrusions à la surface des coupes. Ces protrusions sont colorables par l'acétate d'uranyle et le bromure d'ethidium. Elles sont également reconnues par un anticorps anti-protamine. Elles contiennent donc à la fois de l'ADN et des protéines nucléaires. Les microhétérogénéités de la compaction des noyaux de spermatozoïdes sont ainsi responsables de la colorabilité spécifique des noyaux en microscopie électronique. La technique de Cogliati et Gautier (1973) ne permet pas de révéler la localisation précise de l'ADN des spermatozoïdes puisque les seules parties colorées ont été déplacées à la surface des coupes. Elle est toutefois une des rares techniques utilisable pour visualiser les microhétérogénéités de la compaction des noyaux de spermatozoïdes.

spermatozoïdes épididymaires de lapin / cytochimie ultrastructurale de I'ADN / bromure d'ethidium / immunocytochimie de la protamine / compaction nucléaire des spermatozoïdes

\section{INTRODUCTION}

A major criterion related to mammalian male fertility is the compaction of the sperm chromatin (Gledhill, 1975; Gledhill et al, 1966; Hunter et al, 1976). This can be evaluated by measuring the decondensation ability of the chromatin using, for example, swelling of sperm heads by detergents (Rodriguez et al, 1985; Rosenborg et al, 1990), or quantification of accessible protein side groups such as sulfhydryl groups (Bedford and Calvin, 1974), amino groups (Courtens et al, 1989), or epitopes of the main sperm nucleoprotein, the protamine (Rodriguez et al, 1990). The accessibility of DNA is also one such criterion (Gledhill et al, 1971). This can be evaluated using, for example, intercalating dyes (Courtens et al, 1989) or specific cytochemical procedures such as the Feulgen technique in which hydrolysis of DNA gives rise to pseudo-aldehyde groups, which will be revealed later by a specific dye. This technique is easy to apply to sections or to entire cells (see review by Kasten, 1960) and has been widely used in light microscopy. In spermatozoa, the amount of Feulgen-positive DNA varies after they are released from the testis, and before they achieve fertilisation; the total DNA content per sperm nucleus remains stable (Esnault and Nicolle, 1976). However, the measures of Feulgen-positive DNA, which are straightforward where most somatic cells are concerned, are not so easy to interpret when spermatozoa are investigated. This is mainly due to the fact that the DNA of mammalian sperm nuclei is bound by salt links to only one (or a few) highly basic protein species, the protamine(s). These proteins are, in turn, progressively and reversibly linked together by inter-molecular disulfide bridges which compact the sperm chromatin to different degrees (Bedford and Calvin, 1974; Seligman et al, 1991). Monomers or low MW polymers of protamine are highly soluble in acids (Loir and Lanneau, 1984), including $\mathrm{HCl}$ which is routinely used during the first step of the Feulgen technique. However, when protamines are highly polymerised, they make the sperm nuclei so compact that they could be considered as resistant to 
destructive hydrolysis and less permeable to dyes (Duijndam and Van Duijn, 1975; Esnault and Nicolle, 1976; Porcelli et al, 1979; Nicolle et al, 1986; Guraya, 1986).

The problems of accessibility of the stain to the highly compact sperm chromatin can be theoretically overcome by using ultrathin sections and electron microscopy. At the ultrastructural level, the Feulgen-like procedure of Cogliati and Gautier (1973) was first used by Biggiogera (1986 and 1989) to show micro-heterogeneities in mouse spermatozoa. These data were further confirmed by Courtens et al (1991) who demonstrated that the technique does not reveal all the DNA initially present in the nuclei and that the micro-heterogeneities only appear in spermatid nuclei when the protamines are present. The resulting staining pattern of spermatozoa could be due to at least 2 experimentally demonstrated phenomena: (i) some parts of sperm DNA, masked by nucleoproteins, are not readily accessible to the stain (Biggiogera, 1989); and (ii) the sperm chromatin are more affected by hydrolysis than the somatic chromatin (van Prooijen-Knegt et al, 1980; Redi et al, 1982, 1986), and some of the DNA is released from the samples (Silva and Mello, 1986).

In the present work we have investigated the distribution of nuclear DNA, after $\mathrm{HCl}$ hydrolysis and osmium ammine staining (a Feulgen-like procedure for electron microscopy, Gautier, 1976), in epididymal rabbit spermatozoa exhibiting different degrees of nuclear compaction. The aim of the investigation was to determine under which conditions this procedure could be used to compare different states of chromatin compaction, and to determine whether the staining demonstrates true DNA location in spermatozoa. For this purpose, we have compared the data obtained with 2 other techniques: hydrochloric and hydrolysis followed by uranyle acetate staining or ethidium bromide staining (Biggiogera and Flach Biggiogera, 1989). The effect of hydrolysis on proteins was tested by using a specific anti-protamine antibody. Moreover, specimen tilting proved to be useful in characterising the aspect of the stained nuclear areas.

\section{MATERIALS AND METHODS}

Samples were collected immediately after the slaughter of 6 adult rabbits. Epididymides (head, body and tail) were cut into pieces (about $1 \mathrm{~mm}^{3}$ ) and fixed with $4 \%$ glutaraldehyde in $0.1 \mathrm{M}$ cacodylate $/ \mathrm{HCl}$ buffer, $\mathrm{pH} 7.2$, for $1 \mathrm{~h}$ at $20^{\circ} \mathrm{C}$. Incubation in $0.5 \mathrm{M}$ ammonium chloride in cacodylate buffer for $1 \mathrm{~h}$ at $4^{\circ} \mathrm{C}$ was then used in order to block unreacted aldehyde groups in the tissue. The samples were dehydrated through an ethyl alcohol series before being embedded in LR White resin.

\section{Feulgen-like staining}

Ultrathin sections mounted on bare gold grids were hydrolysed by flotation on $5 \mathrm{~N}$ hydrochloric acid for $5-40 \mathrm{~min}\left(5 \mathrm{~min}\right.$ steps) at $20^{\circ} \mathrm{C}$, following the technique of Cogliati and Gautier (1973). After a brief wash in distilled water, the grids were floated for $1 \mathrm{~h}$ at $20^{\circ} \mathrm{C}$ on drops of $0.5 \%$ osmium ammine prepared according to Olins et al (1989), and freshly saturated with gaseous sulphurous anhydride. This technique is hereafter referred to as $\mathrm{HCl}$-Os staining.

Some hydrolysed sections were stained with $2 \%$ aqueous uranyl acetate (which binds to nucleic acids and proteins) for $20 \mathrm{~min}$ at $20^{\circ} \mathrm{C}$ rather than with osmium ammine. The intensity of the reaction was evaluated on micrographs by calculating the ratio between the total surface of the stained spots (or speckles) and that of the nuclear section, using the grid technique of Solari (1973). A grid made of lines spaced by $5 \mathrm{~mm}$ both vertically and horizontally, drawn on a transparent support, was applied against micrographs enlarged to 40000 and the presence or absence of heavily stained nuclear parts (further referred to as speckles, see figs 1-12) under the intersections of the grid were recorded. In each sample, 15 longitudinal sections of nuclei (displaying acrosome, equatorial segment, and postacrosomal area) were measured, and the results were compared using the Student's $T$ test. 


\section{Ethidium bromide/phosphotungstate staining}

Ultrathin sections, mounted on gold grids, were processed according to Biggiogera and Flach Biggiogera (1989). They were floated on drops of ethidium bromide in water $(100 \mu \mathrm{g} / \mathrm{ml})$ for $30 \mathrm{~min}\left(20^{\circ} \mathrm{C}\right)$ before being reacted with $1 \%$ aqueous sodium phosphotungstate $(\mathrm{pH} 7)$ for $30 \mathrm{~min}$ at $20^{\circ} \mathrm{C}$. Some sections were stained after hydrolysis by flotation on $5 \mathrm{~N}$ hydrochloric acid for $20 \mathrm{~min}$ at $20^{\circ} \mathrm{C}$, followed by a brief rinse is distilled water.

\section{Immunocytochemical demonstration of protamine}

Untreated or of hydrolysed ultrathin sections $(5 \mathrm{~N}$ $\mathrm{HCl}, 20^{\circ} \mathrm{C}, 10$ or $20 \mathrm{~min}$ ), mounted on gold grids were incubated by flotation for $20 \mathrm{~min}$ on 1:10 goat serum in PBS (phosphate buffer saline, $\mathrm{pH}$ 8.0) before 1:500 rabbit anti-ram protamine serum (Courtens et al, 1983) was added and the incubation prolonged for $17 \mathrm{~h}$ at $4^{\circ} \mathrm{C}$ in a humid chamber. After several washes in PBS, the sections were floated for $20 \mathrm{~min}$ at $20^{\circ} \mathrm{C}$ on PBS containing $1: 20$ colloidal gold $(13 \mathrm{~nm})$ coupled to antirabbit IgG.

\section{RESULTS}

\section{$\mathrm{HCl}$-Os staining}

Typical $\mathrm{HCl}-\mathrm{Os}$ staining patterns of spermatozoa from the head, body and tail of the epididymis are presented in figs $1-12$, in the order of increasing duration of hydrolysis. The reaction gave rise to stained speckles regardless of the time of hydrolysis and the origin (head-to-tail epididymis) of spermatozoa. The speckles were surrounded by a more or less stained nuclear background, representing both the reaction product and the natural opacity of the nuclei. In sections tilted in a goniometric stage, the speckles appeared to be protruding from the surface of the sections, sitting over the grey background of nuclei (fig 13).

In most of the compact nuclei (epididymis tail, figs $3,6,9,12$ ), the first appearance of the staining, the optimal reaction time, and the final disappearance of reactivity, occurred later than in less compact nuclei (epididymis head, figs 1, 4, 7, 10 and epididymis body figs $2,5,8,11$ ). However, after 40 min hydrolysis, and whatever the origin of spermatozoa, the chromatin of most nuclei was bleached to such an extent that it appeared lighter than the resin surrounding the cells, suggesting that not only the DNA, but probably other nuclear components might be lost (figs 10-11).

The chromatin of the somatic cells in the epididymal epithelium displayed the usual staining pattern (fig 18) and virtually no or few modifications were observed when $\mathrm{HCl}$ hydrolysis varied from 10 to $40 \mathrm{~min}$.

The staining intensity of sperm nuclei, expressed as the relative surface of the speckles, was dependent upon both the

Fig 1-12. High magnifications of longitudinal sections through nuclei of spermatozoa issued from the head (left lane), body (central lane) and tail (right lane) of rabbit epididymis. The sections were hydrolysed with $5 \mathrm{~N} \mathrm{HCl}$ for the time ( $\mathrm{min}$ ) indicated in the upper right corner of each micrograph, before being stained for $1 \mathrm{~h}$ with osmium ammine. Magnifications: (1) 81600 ; (2) 73600 ; (3) 86800 ; (4) 89000 ; (5) 95 400; (6) 89 000; (7) 99 000; (8) 55 800; (9) 60 000; (10) 43 300; (11) 41000 ; (12) 80 000. For short hydrolysis duration, the ground nuclear material appears more or less grey (1, 2 and 3 ) and it becomes pale as hydrolysis progresses. After the longest hydrolysis time, the nucleus is not stained (10 and 11). The stained areas consist of diffuse or concentrated spots at the surface of the sections. The maximal intensities, considered as stained surface density, varied according to the origin of the sample. Ten min hydrolysis for epididymal head, 15 min for epididymal body, and 25 min for the spermatozoa from tail epididymis were found to be optimal. Note that in samples exhibiting high nuclear compaction (tail), the staining appears gradually. The nuclear area is never totally stained, regardless of the duration of hydrolysis. 

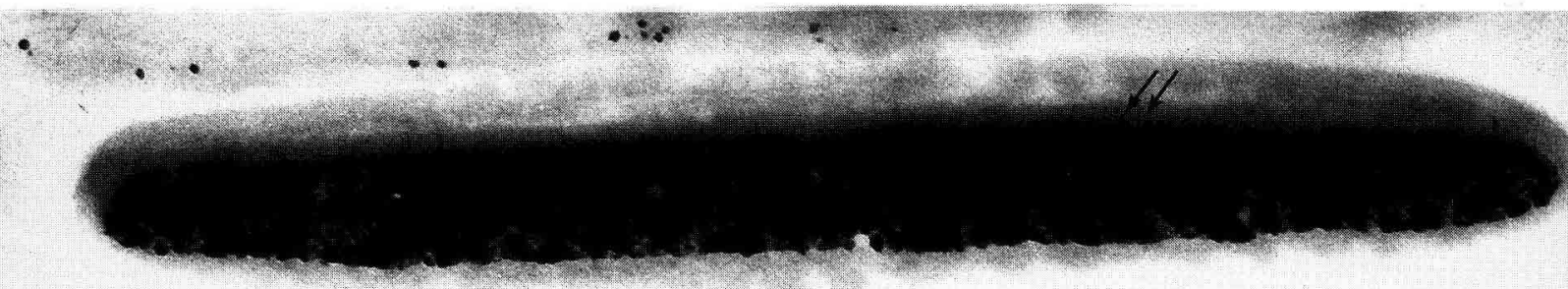

E. $\quad+\cdots+\cdots$

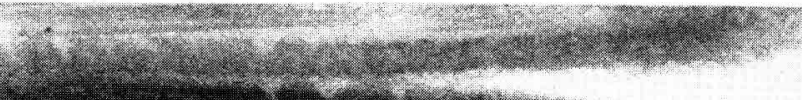

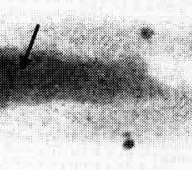

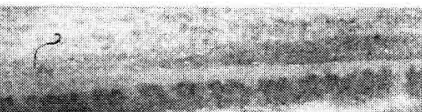

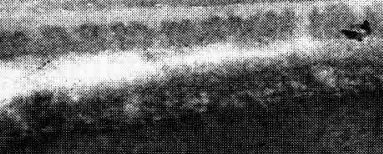

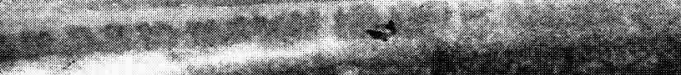

-

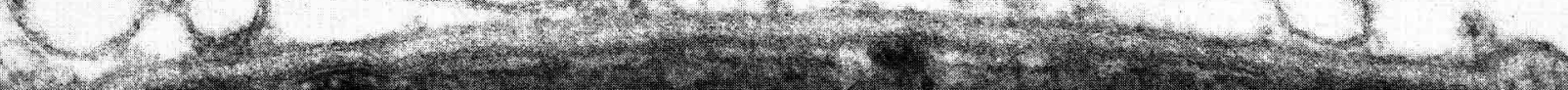

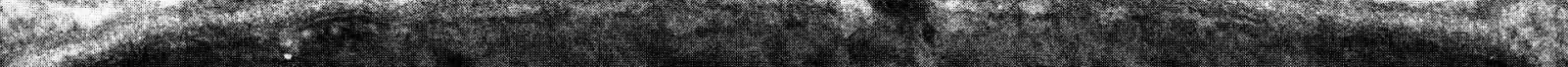

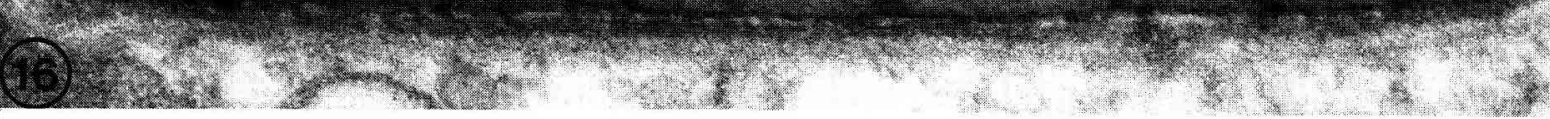

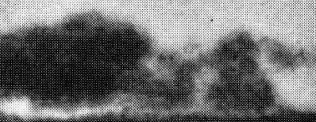
(3)

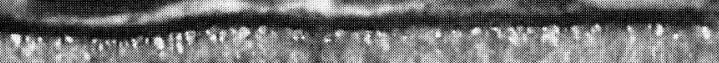


duration of hydrolysis and the degree of maturation of the cells (fig 21). The only remarkable point of each of the non-linear curves corresponded to the maximum intensity/optimal hydrolysis.

\section{HCl-uranyl acetate staining}

Following this staining, speckles similar in size and distribution to those described above were observed. After hydrolysis for a short duration, the nuclear background was high, suggesting that DNA and/or proteins were still present in the internal layers of the sections (fig 14). For longer hydrolysis, the nuclear background was lowered and speckles were still stained. Moreover, after $40 \mathrm{~min}$ hydrolysis, no parts of nuclei were stained, similarly to the situation observed after $\mathrm{HCl}$-osmium ammine treatment.

\section{Ethidium bromide staining}

When used without hydrolysis, the lamellae normally present in rabbit sperm nuclei (Koehler, 1970) were outlined by discrete foci at the surface of the sections (fig 15).
This pattern was similar in all epididymal spermatozoa without marked differences for cells of different maturation stage. However, after $\mathrm{HCl}$ hydrolysis, a dramatic reorganisation of the stained material was observed. Large speckles, similar in size to those described above were now stained, and the alignments of foci were lost (fig 16). After 40 min hydro-lysis, the nuclei were no longer stained, and some occasional small holes in the sections revealed an extensive extraction of nuclear substance (fig 17).

\section{Immunocytochemical demonstration of protamine}

As described earlier, the anti-ram protamine antibody cross-reacted with rabbit protamine (Plöen et al, 1989). As has been observed previously in pig epididymal spermatozoa (Rodriguez et al, 1990), the immunoreaction was weak on non-hydrolysed sections, whatever the origin of the spermatozoa (fig 19). The immunocytochemical reaction strongly increased after $\mathrm{HCl}$ hydrolysis of sections. The speckles described above in all epididymal spermatozoa were the most intensively labelled nuclear structures (fig 20).

Fig 13. Stereopair of a tail epididymis spermatozoon stained with osmium ammine after hydrolysis of the section for $20 \mathrm{~min}$ with $5 \mathrm{~N} \mathrm{HCl}$. The sections are tilted $+/-30$ degrees. Note that the stained parts are protruding from the section plane. This can be evidenced without a special stereo viewer when comparing the bottom borders of the nucleus in both pictures. The border in the above picture is irregular compared with that in the lower picture. When comparing both pictures, it appears that the heavy staining is restricted to the surface of the section, while the depth of the section is only moderately grey (double arrow). Magnification: 46500 .

Fig 14. Spermatozoon from the tail epididymis stained with uranyl acetate after $\mathrm{HCl}$ hydrolysis for $20 \mathrm{~min}$. Speckles similar in size as those present after osmium ammine are stained. Some parts of the nuclei are faintly stained (arrow). Magnification: 18000.

Fig 15. Spermatozoon from the body epididymis, no hydrolysis. The spots of ethidium bromide/phosphotungstate are aligned along virtual lines in the nucleus. Magnification: 44800 .

Fig 16. Spermatozoon from the body epididymis. The section was hydrolysed for $20 \min$ in $5 \mathrm{~N} \mathrm{HCl}$ before being counterstained with ethidium bromide followed by phosphotungstate. As compared with figure 15, no alignments of spots are visible. Instead, large patches are evidenced over the nucleus. Magnification: 42000.

Fig 17. Spermatozoon from tail epididymis. The section was hydrolysed for $40 \min$ in $5 \mathrm{~N} \mathrm{HCl}$ before being stained with ethidium bromide and phosphotungstate. The nuclear contents are extensively extracted. Magnification: 16000. 

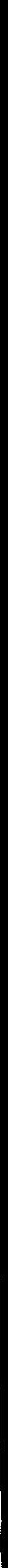

Fig 18. Epithelium of the head epididymis hydrolysed for $20 \mathrm{~min}$ in $5 \mathrm{~N} \mathrm{HCl}$ and stained with osmium ammine. The chromatin displays classical distribution. Magnification: 6000

Fig 19. Immunocytochemical demonstration of protamine in a spermatozoon from the tail epididymis. Owing to compaction of the chromatin, the antibody has limited access to the epitopes. Magnification: 32000 .

Fig 20. Immunocytochemical demonstration of protamine in a spermatozoon from the tail epididymis after $\mathrm{HCl}$ hydrolysis for $10 \mathrm{~min}$. Epitopes are now available to bind the antibody in several regions of the sperm head. These regions display size similar to the speckles stained by osmium ammine, uranyl acetate, or ethidium bromide. Magnification: 44500 


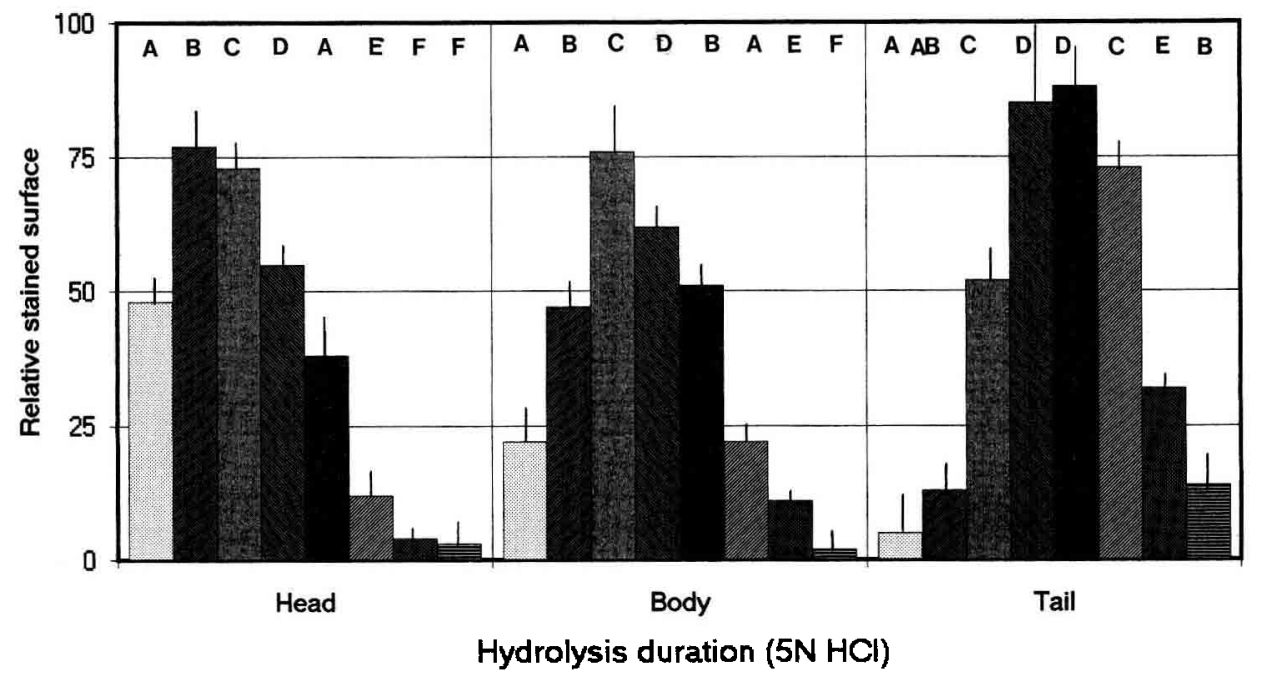

Fig 21. Ratio of stained nuclear area to total nuclear surface of epididymal sperm nuclei. Bars \pm standard deviation. The maxima of staining intensity are close to 10,15 and 25 min hydrolysis for spermatozoa issued from the head, body and tail epididymis, respectively. The columns labelled by the same letters $(A-F)$ are not significantly different $(p<0.05)$ within 1 experimental group (head, body, tail). The nuclei are almost unstained after 30,35 and 40 min hydrolysis, respectively, according to the epididymal origin of the spermatozoa, suggesting that most of the DNA has been destroyed inside the sections. $5 \mathrm{~min} ; 10 \mathrm{~min} ; 15 \mathrm{~min} ; 20 \mathrm{~min} ; 25 \mathrm{~min} ; 30 \mathrm{~min} ; 35$ min; 国 $40 \mathrm{~min}$.

\section{DISCUSSION}

When used on optimally hydrolysed sections of somatic cells, the Feulgen reaction provides unambiguous localisation of DNA (Gautier, 1976; Schulte and Wittekind, 1990). The present results also show that the distribution of DNA in nuclei of the epididymal somatic cells is not notably modified after hydrolysis for 10-40 min.

However, our results on rabbit spermatozoa show that, independently of the mean nuclear compaction of a given cell, chromatin is not homogeneously affected by hydrolysis. This phenomenon is confirmed by 3 different staining techniques. One part of the chromatin is probably lost very early during $\mathrm{HCl}$ treatment, while the most condensed parts of nuclei resist for a longer time. This behaviour is species- and spermatozoon-specific. It gives rise to unusual staining patterns: leopard-skin-like in the mouse (Biggiogera, 1986, 1989); pea-like staining in the bull (Courtens et al, 1991), and speckles in the rabbit epididymal spermatozoa (this work). In addition, they also differ within the same species: the lamellae demonstrated in rabbit testicular spermatozoa (Courtens et al, 1991) are replaced by speckles in more mature epididymal sperm. Since lamellae were shown in many mammalian sperm nuclei, including the rabbit, by different dyes or physical techniques (Koehler, 1970), and are also visualised in 
rabbit epididymal spermatozoa by ethidium bromide staining before hydrolysis (this work), the question arises as to a redistribution of nuclear material during the Feulgen-like procedure. Speckles are only present after hydrolysis independently of the dye used in the second step of the technique. Moreover, the use of a goniometric stage reveals that they protrude at the surface of the sections. They contain DNA, stained by either ethidium bromide (a strain for nucleic acids; sperm nuclei do not contain RNA) or osmium ammine (a stain for free aldehyde and ketone groups). The staining by uranyl acetate is more questionable in regard to DNA specificity, since proteins are also revealed. However, the speckles also contain at least 1 nucleoprotein, the protamine detected by immunocytochemistry. We conclude, thus, that a dramatic reorganisation of the nuclear structure occurs in spermatozoa during $\mathrm{HCl}$ hydrolysis. This is characterised by the extraction, swelling and displacement of the nuclear constituents towards the surface of the sections. The ultrastructural distribution pattern of sperm DNA obtained by the Feulgen-like technique, should therefore be interpreted with great caution.

The hydrolysis curves presented in this study are not fundamentally different from those obtained on whole spermatozoa prepared for photonic measurements such as microspectrophotometry (Esnault and Nicolle, 1976), or cytofluorimetry (Courtens et al, 1989). The only result that correlates with the nuclear packaging is the hydrolysis time at which the maximum staining intensity is obtained. When different sperm samples are to be compared using this technique, it is therefore necessary to accurately determine this point for each of the compared samples.

In spite of these limitations, which seem to be restricted to spermatozoa, the Feulgen-like technique remains one of the few techniques able to enhance and demon- strate micro-heterogeneities in sperm nuclei. The present data suggest that the protection of sperm DNA by highly cross-linked protamine molecules is not homogeneous within 1 sperm nucleus and that it is also modified when cells leave the testis and go through maturation stages in the epididymis. These micro-heterogeneities could explain why the sperm chromatin can be so rapidly modified in vivo by changes in the ionic environment (Kvist et al, 1987; Courtens et al, 1989).

\section{ACKNOWLEDGMENTS}

This work, started during a sabbatical visit of one of the authors (JLC) to the University of Lausanne, was supported by grants from the Swiss National Science Foundation (3126417.89), INRA, 'AIP Régulation intragonadique', Fondation du 450 Anniversaire de l'Université de Lausanne and Fonds du Docteur Ernest Rub, Lausanne. We are indebted to A Gautier for his stimulating discussions throughout the progression of this work, A Begue for photographic work, and I Courtens for help with the language traps.

\section{REFERENCES}

Bedford JM, Calvin H (1974) The occurrence and possible significance of S-S crosslinks in sperm heads with particular reference to eutherian mammals. J Exp Zool 188,137-156

Biggiogera M (1986) Unusual ultrastructural feature of chromatin in mouse sperm cells after DNA staining with osmium ammines. Basic Appl Histochem 30, 501-504

Biggiogera $M$ (1989) Chromatin arrangement in mouse sperm nuclei: an ultrastructural cytochemical study. Mol Reprod Develop 1, 9197

Biggiogera M, Flach Biggiogera F (1989) Ethidium bromide- and propidium iodide-PTA staining of nucleic acids at the electron microscopic level. $J$ Histochem Cytochem 37, 1161-1166

Cogliati R, Gautier A (1973) Mise en évidence de I'ADN et des polysaccharides à l'aide d'un 
nouveau réactif "de type Schiff". CR Acad Sci (Paris) 276, 3041-3044

Courtens JL, Delaleu B, Dubois M, Lanneau M, Loir M, Rozinek J (1983) Immunocytochemical localization of protamine in the spermatids of the ram. Gamete Res 8, 21-28

Courtens JL, Paquignon M, Blaise F, Ekwall $H$, Plöen $L$ (1989) Nucleus of the boar spermatozoon: structure and modifications in frozen, frozen-thawed, or sodium dodecyl sulfatetreated cells. Mol Reprod Develop 1, 264277

Courtens JL, Biggiogera M, Fakan S (1991) A cytochemical and immunocytochemical study of DNA distribution in spermatid nuclei of mouse, rabbit and bull. Cell Tiss Res 265 , $517-525$

Duijndam WAL, Van Duijn P (1975) The influence of chromatin compactness on the stoichiometry of the Feulgen-Schiff procedure studied in model films. II. Investigations on films containing condensed or swollen chicken erythrocytes nuclei. J Histochem Cytochem 23, 891-900

Esnault CE, Nicolle JC (1976) Evolution de I'ADN et des protéines nucléaires basiques en cours de la maturation des cellules germinales du bélier. Ann Histochem 21, 187-197

Gautier A (1976) Ultrastructural localization of DNA in ultrathin tissue sections. Int Rev Cytol $44,114-170$

Gledhill BL (1975) The Biology of the Male Gamete (JG Duckett, PA Racey, eds), Academic Press, London, NY, 215-226

Gledhill BL, Gledhill MD, Rigler R, Ringertz NR (1966) Changes in deoxyribonucleoprotein during spermiogenesis in the bull. Exp Cell Res 41, 652-665

Gledhill BL, Darzynkiewicz Z, Ringertz NR (1971) Changes in deoxyribonucleoprotein during spermiogenesis in the bull: increased $(3 \mathrm{H})$ actinomycin $\mathrm{D}$ binding to nuclear chromatin of morphologically abnormal spermatozoa. $J$ Reprod Fertil 26, 25-38

Guraya SS (1986) Biology of Spermatogenesis and Spermatozoa in Mammals. Springer Verlag, Berlin

Hunter JD, Bodner AJ, Hatch Ft, Balhorn RL, Mazrimas JA, McQueen AP, Gledhill BL (1976) Single-strand nuclease action on heat denatured spermiogenic chromatin. J Histochem Cytochem 24, 901-907
Kasten FH (1960) The chemistry of Schiff's reagent. Int Rev Cytol 10, 1-93

Koehler JK (1970) A freeze-etching study of rabbit spermatozoa with particular reference to head structures. J Ultrastruct Res 33, 598614

Kvist U, Björndahl L, Kjellberg S (1987) Sperm nuclear zinc, chromatin stability, and male fertility. Scanning Microsc 1, 1241-1247

Loir M, Lanneau M (1984) Structural function of the basic proteins in ram spermatids. JU/trastruct Res 86, 262-276

Nicolle JC, Fournier-Delpech S, Courot M (1986) Influence of uterine secretions on the chromatin of ram spermatozoa at different stages of maturation: cytophotometric study of Feulgen-DNA after in vitro incubation. Gamete Res 11, 321-328

Olins AL, Moyer BA, Kim S-H, Allison DP (1989) Synthesis of a more stable osmium ammine electron-dense stain. $J$ Histochem Cytochem 37, 395-398

Plöen L, Courtens JL, Muller S, Rozinek J (1989) An immunocytochemical study of somatic histones during spermiogenesis in the rabbit. $\checkmark$ Ultrastruct Mol Struct Res 102, 297-298

Porcelli F, Lauria A, Redi CA, Fraschini A, Formenti D (1979) Ricerche citochimiche sul complesso DNA-proteine di spermatozoi di tori fertili ed ipofertili. Riv Zootecn Veterinaria 6 , 401-411

Redi CA, Garagna S, Pellicciari C (1982) Cytochemical assessment of chromatin characteristics during sperm cytodifferentiation in mouse. Basic App/ Histochem 26, 227-237

Redi CA, Garagna S, Bottiroli G (1986) Cytochemical evaluation of sperm and lymphocyte DNA content after treatment with $5 \mathrm{~N} \mathrm{HCl}$. Histochemistry 84,41-44

Rodriguez $\mathrm{H}$, Ohanian $\mathrm{C}$, Bustos-Obregon $\mathrm{E}$ (1985) Nuclear chromatin decondensation of chromatin in vitro: a method for evaluating the fertilizing ability of ovine semen. Int $J$ Androl 8 , 147-185

Rodriguez-Martinez $\mathrm{H}$, Courtens JK, Kvist $\mathrm{U}$, Plöen L (1990) Immunocytochemical localization of nuclear protamine in boar spermatozoa during epididymal transit. $J$ Reprod Fert 89, 591-595

Rosenborg L, Rao KM, Björndahl L, Kvist U, Pousette A, Akerlöf E, Fredricsson B (1990) 
Changes in human sperm chromatin stability during preparation for in vitro fertilization. Int $J$ Androl 13, 287-296

Schulte EKW, Wittekind DH (1990) Standardization of the Feulgen reaction: the influence of chromatin condensation on the kinetics of acid hydrolysis. Anal Cell Pathol 2, 149-157

Seligman J, Shalgi R, Oschry Y, Kosower NS (1991) Sperm analysis by flow cytometry using the fluorescent thiol labelling agent monobromobimane. Mol Reprod Develop 29, 276281
Silva MJL, Mello MLS (1986) Lability to acid hydrolysis in some different DNA-protein complexes of spermatozoa. Acta Histochem 78, 197-215

Solari A (1973) Etude quantitative d'organes ou de tissus. I. Méthodes d'estimation des volumes. Ann Biol Anim Biochem Biophys 13, 247-265

Van Prooijen-Knegt AC, Redi CA, Van der Ploeg M (1980) Quantitative aspects of the cytochemical Feulgen-DNA procedure studied on model systems and cell nuclei. Histochemistry $69,1-17$ 